UDC: $597.851: 591.15(477.8)$

\title{
PHENES OF WATER FROGS (PELOPHYLAX) AS THE INDICATORS OF WATER BODIES' CONTAMINATION IN PRE-CARPATHIANS, ROZTOCHIA, LESSER AND WESTERN POLISSIA
}

\author{
V. O. Stakh1, I. S. Khamar', O. S. Reshetylo', Yu. M. Zabytivskyi ${ }^{2}$ \\ ${ }^{1}$ Ivan Franko National University of Lviv, 4, Hrushevskyi St., Lviv 79005, Ukraine \\ ${ }^{2}$ Lviv Research Station of Institute of Fisheries, NAAS \\ 11, Lvivska St., Velykyi Lubin, Horodok District, Lviv Region 81555, Ukraine \\ e-mail: vasulunastax@gmail.com
}

The results of phenotypic variability of water frogs (Pelophylax) analysis depending on internal and external influence factors are presented. 345 individuals of three species (Marsh Frog, Pool Frog and Edible Frog) were taken for the analysis from water bodies of different level of anthropogenic influence. The hydrochemical composition of water from the investigated aquatic ecosystems was analyzed, and the classification of water bodies after their water quality was done. The expression rates of nine phenotypes depending on the species of frog, its age stage and water quality class were established. It was found out that all the analyzed phenes show a significant dependence on the habitat conditions. The expression rates of middorsal stripe, as well as the coloration of femur and tibia depend mostly on water bodies' contamination level. The increasing level of chemical contamination changes the ratios of alternative variants of middorsal stripe, and coloration of femur and tibia. New variants in coloration of femur and tibia that have never been described were noticed. Pelophylax individuals from the most contaminated water bodies (Cholgyni, Perekalky and Zhovtantsi) showed the highest variability by the analyzed phenes.

Keywords: Pelophylax esculentus complex, polymorphism, hydrochemistry, middorsal stripe, femur and tibia coloration.

\section{INTRODUCTION}

The adaptive polymorphism of amphibians can be used during the research of their population reactions on the changes of habitat conditions. Adaptive polymorphism is the existence of two or more genetically and phenetically distinct forms which dominate under different conditions (temperature, light, chemical composition of aquatic habitat, presence of predators, population density, etc.) [18].

Phenetically distinct forms (phenes) are the discrete (sharply detached from others), elementary (simple, indivisible without of quality loss), alternative (existing in two or more variants) hereditary traits that are the result of genes-environment interactions during the ontogenesis. There is described a number of phenes with different expression rates for Anura [6].

ISSN 1996-4536 (print) • ISSN 2311-0783 (on-line) • Біологічні Студії / Studia Biologica • 2017 • Том 11/№1 • С. 161-168 


\section{MATERIALS AND METHODS}

The material was collected in 2011-2016 according to the generally adopted in batrachology method of dip-netting [2] in the water bodies of Pre-Carpathians, Roztochia, Lesser and Western Polissia (Fig. 1).

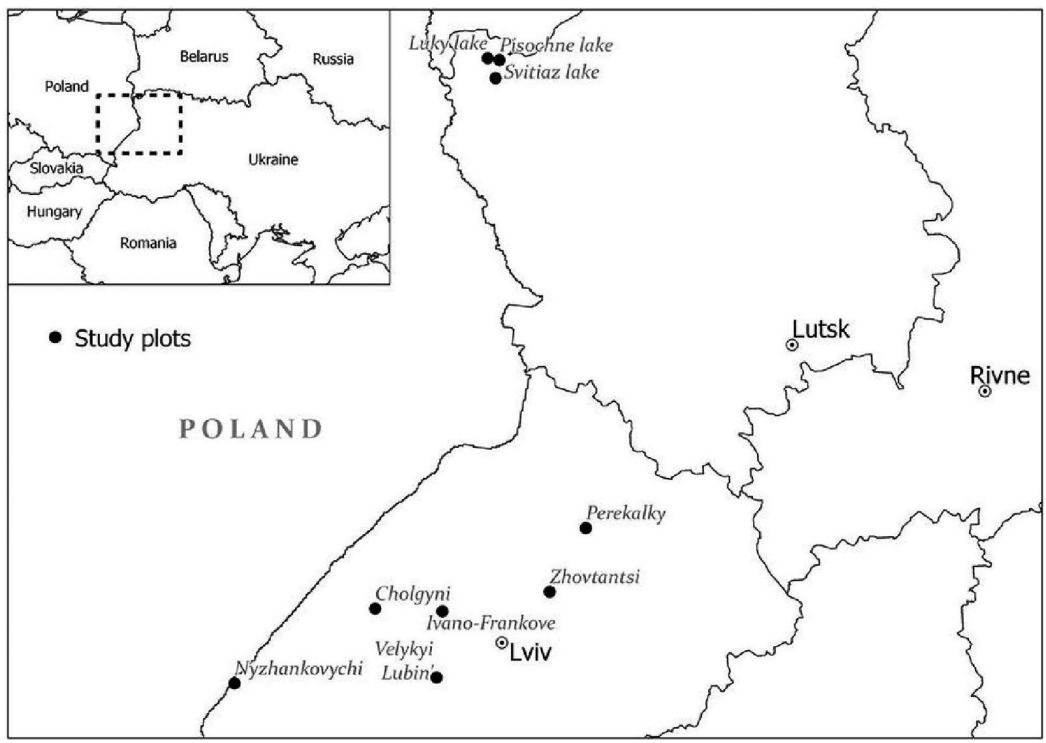

Fig. 1. Localization of the investigated water bodies

Рис. 1. Локалізація досліджуваних водойм

There are three species of water frogs on the territory of Ukraine: Marsh Frog Pelophylax ridibundus [Pallas, 1771], Pool Frog - Pelophylax lessonae [Camerano, 1882 «1881»] and their hybrid - Edible Frog - Pelophylax esculentus [Linnaeus, 1758]. There were sampled 345 individuals of Pelophylax (Table 1); species differentiation of the frogs is confirmed by genetic analysis [11].

Table 1. The number of Pelophylax individuals sampled in the investigated water bodies Таблиця 1. Кількісна представленість представників роду Pelophylax, відібраних у досліджуваних водоймах

\begin{tabular}{l|l|l|l} 
Water bodies & Pelophylax ridibundus Pelophylax lessonae & Pelophylax esculentus
\end{tabular}

\begin{tabular}{|l|c|c|c|}
\hline Pisochne & 26 & 21 & 34 \\
\hline Svitiaz & - & 7 & 4 \\
\hline Luky & 4 & 5 & - \\
\hline Nyzhankovychi & 75 & - & 1 \\
\hline Velykyi Lubin & 34 & 9 & - \\
\hline Ivano-Frankove & 16 & - & 12 \\
Cholgyni & 22 & 24 & 1 \\
\hline Zhovtantsi & 19 & - & - \\
\hline Perekalky & 20 & - & P
\end{tabular}

ISSN 1996-4536 (print) •ISSN 2311-0783 (on-line) • Біологічні Студії / Studia Biologica • 2017 • Том 11/№1 • C. 161-168 
The description of phenotypes of water frogs was made on the following features taking into account their alternative variants: middorsal stripe, dorsal maculation, ventral coloration, throat coloration, femur and tibia coloration, presence of snout stripes, presence of yellow spots on the thigh, dorsal coloration and eyes color [2, 6, 8, 10, 16].

General background of the coloration was determined according to "Colour scale" [4] under the daylight illumination. Since general background of coloration of the same individual can change depending on humidity, temperature and illumination [5], all sampled frogs were kept for several hours in the identical conditions before their coloration description.

The hydrochemical samples were taken according to the generally adopted methods [1]. The samples analysis was carried out in the certified chemical laboratory of Lviv Research Station of Institute of Fisheries of NAAS. Such indices as $\mathrm{pH}$, water hardness, total mineralization, $\mathrm{NH}^{+}, \mathrm{NO}_{2}^{-}, \mathrm{NO}_{3}^{-} \mathrm{PO}_{4}{ }^{3-}, \mathrm{Cl}^{-}, \mathrm{SO}_{4}{ }^{2-}$, hydrogen carbonate content, dissolved oxygen, dichromate oxidability, and biological oxygen consumption were determined [9].

\section{RESULTS AND DISCUSSION}

The variability of feature is determined by the genetic spectrum of reaction norm and factor that influences on the expression rate of the feature. For the determination of influence level of the analyzed factors (water body type, species of frog and its age stage), it was necessary to carry out the group comparison. Kruskal-Wallis test was used to find out the dependence between the factor and the feature [7]. It lets us compare the medians of more than two sample groups. The test can check the null hypothesis saying that the medians of the feature in the populations (sample groups) are equal. The higher value test shows, the more significant feature is. So, using this non-parametric test we found out the dependence of features from the analyzed factors. Test results with the confidence levels are presented in Table 2.

Table 2. The dependence of factor influence on the feature expression (Kruskal-Wallis test) Таблиця 2. Залежність впливу факторів на прояв ознаки (тест Краскела-Волліса)

\begin{tabular}{|l|c|c|c|c|c|c|}
\hline \multicolumn{1}{|c|}{ Feature } & \multicolumn{2}{|c|}{ Water body } & \multicolumn{2}{c}{ Species } & \multicolumn{2}{c|}{ Age } \\
\hline & $\mathrm{H}$ & $\mathrm{p}$ & $\mathrm{H}$ & $\mathrm{p}$ & $\mathrm{H}$ & $\mathrm{p}$ \\
\hline Middorsal stripe & 33.113 & $\mathbf{0 . 0 0 0 0}$ & 4.414 & 0.1100 & 4.119 & 0.1275 \\
\hline Dorsal coloration & 16.413 & $\mathbf{0 . 0 0 0 3}$ & 38.185 & $\mathbf{0 . 0 0 0 0}$ & 1.235 & 0.5394 \\
\hline Dorsal maculation & 57.086 & $\mathbf{0 . 0 0 0 0}$ & 34.714 & $\mathbf{0 . 0 0 0 0}$ & 14.710 & $\mathbf{0 . 0 0 0 6}$ \\
\hline Ventral coloration & 22.604 & $\mathbf{0 . 0 0 0 0}$ & 4.607 & 0.0999 & 84.583 & $\mathbf{0 . 0 0 0 0}$ \\
\hline Throat coloration & 40.160 & $\mathbf{0 . 0 0 0 0}$ & 2.027 & 0.3629 & 36.831 & $\mathbf{0 . 0 0 0 0}$ \\
\hline Snout stripes & 19.380 & $\mathbf{0 . 0 1 3 0}$ & 2.368 & 0.306 & 12.017 & $\mathbf{0 . 0 0 2 5}$ \\
\hline Thigh yellow spots & 29.175 & $\mathbf{0 . 0 0 0 0}$ & 26.298 & $\mathbf{0 . 0 0 0 0}$ & 4.303 & 0.1163 \\
\hline Eyes color & 9.870 & $\mathbf{0 . 0 0 7 2}$ & 34.387 & $\mathbf{0 . 0 0 0 0}$ & 7.501 & $\mathbf{0 . 0 2 3 5}$ \\
\hline Femur and tibia coloration & 11.809 & $\mathbf{0 . 0 0 2 7}$ & 0.276 & 0.8713 & 1.582 & $\mathbf{0 . 4 5 3 4}$
\end{tabular}

Comments: the significant values of factors influencing on the feature expression are shown in bold

Примітка: жирним виділено достовірність значень факторів, які значимо впливають на прояв аналізованих ознак

ISSN 1996-4536 (print) • ISSN 2311-0783 (on-line) • Біологічні Студії / Studia Biologica • 2017 • Том 11/№1 • С. 161-168 
According to the table the water body type influences on the expression of all the analyzed phenotypic features to the certain extent. Middorsal stripe as well as femur and tibia coloration are the phenes which expression rates significantly depend on physicochemical peculiarities of habitat. The status of such phenes as dorsal coloration and yellow spots on the thigh depend on both species of frog and water body conditions. Ventral coloration, throat coloration, and snout stripes are the phenes which status is defined by the individual age stage and habitat conditions. Eyes color and dorsal maculation of the frogs depend on all three given factors.

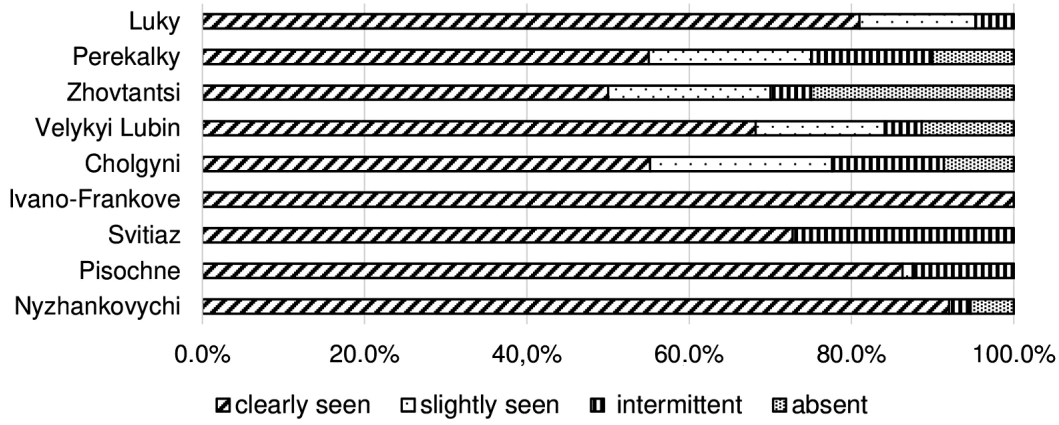

Fig. 2. The distribution of middorsal stripe variants in water frogs from the study plots

Рис. 2. Розподіл станів дорзомедіальної смуги в представників зелених жаб у досліджуваних водоймах

Middorsal stripe has four variants: clearly seen, slightly seen, intermittent, absent. The comparison of middorsal stripe variants of water frogs from the study plots points out the individuals without the stripe in water bodies of Perekalky, Zhovtantsi, Velykyi Lubin, Cholgyni and Nyzhankovychi (Fig. 2). It doesn't depend on the species of frog and its age as we have ascertained already (Table 2), so the dominant factor causing such a response of the organism is physicochemical conditions of its habitat.

The next phene that shows significant dependence from habitat conditions is femur and tibia coloration. It has three alternative variants: continuous cross stripes, intermittent cross stripes and spots. The detailed analysis of the maximal variability of this feature gives us the following distribution: Perekalky, Velykyi Lubin, Cholgyni, Pisochne, and Nyzhankovychi (Fig. 3).



Fig. 3. The distribution of femur and tibia coloration variants in water frogs from the study plots

Рис. 3. Розподіл станів забарвлення стегна та гомілки в представників зелених жаб у досліджуваних водоймах

ISSN 1996-4536 (print) • ISSN 2311-0783 (on-line) • Біологічні Студії / Studia Biologica • 2017 • Том 11/№1 • C. 161-168 
Water frogs are the most aquatic ones among the amphibians of Ukraine; they remain in water after the breeding. So that physicochemical characteristics of water play an important role in the amphibian vital activity. There is no single index to characterize water quality in total therefore optimal is to use a number of them. Studied aquatic ecosystems of Pre-Carpathians, Roztochia, Lesser and Western Polissia were classified according to the generally adopted method of ecological evaluation of the surface waters quality [9]. As a result of chemical analysis of water we have got the classification of investigated water bodies by their water quality (Table 3).

\section{Table 3. Classification of the investigated water bodies by their water quality}

Таблиця 3. Класифрікація досліджуваних водойм за якістю їхньої води

\begin{tabular}{|c|c|c|c|c|c|c|c|c|c|}
\hline Territory & 齐 & 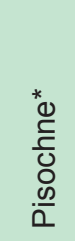 & 菑 & 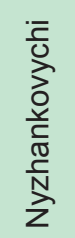 & 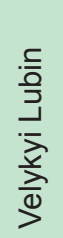 & 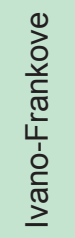 & 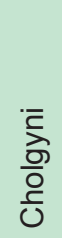 & $\begin{array}{l}\bar{w} \\
\stackrel{9}{c} \\
\frac{\pi}{5} \\
0 \\
0 \\
\frac{T}{N}\end{array}$ & 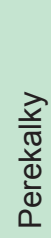 \\
\hline Water quality class & II & II & II & II & II & II & III & III & III \\
\hline Water quality category & 2 & 2 & 2 & 3 & 3 & 3 & 4 & 4 & 4 \\
\hline $\begin{array}{l}\text { Category name by purity degree } \\
\text { (contamination) }\end{array}$ & \multicolumn{3}{|c|}{ Clean } & \multicolumn{3}{|c|}{ Clean enough } & \multicolumn{3}{|c|}{$\begin{array}{l}\text { Slightly } \\
\text { contaminated }\end{array}$} \\
\hline Trophics (dominating type) & \multirow{2}{*}{\multicolumn{3}{|c|}{$\begin{array}{c}\text { Mesotrophic } \\
\alpha^{\prime} \text {-olygosaprobic }\end{array}$}} & \multirow{2}{*}{\multicolumn{3}{|c|}{$\begin{array}{c}\text { Mesoeutrophic } \\
\beta^{\prime} \text {-mesosaprobic }\end{array}$}} & \multirow{2}{*}{\multicolumn{3}{|c|}{$\begin{array}{c}\text { Eutrophic } \\
\beta^{\prime \prime} \text {-mesosaprobic }\end{array}$}} \\
\hline Saprobity & & & & & & & & & \\
\hline
\end{tabular}

Comment: * - the results of chemical analysis are taken from Sytnyk et al [13-15]

Примітка: * - результати хімічного аналізу взяті з робіт Ситника зі співавторами [13-15]

The lakes of Western Polissia (Luky, Pisochne, Svitiaz in Shatsk National Nature Park) have similar chemical composition of water and have been referred to clean category. The water bodies of Nyzhankovychi, Velykyi Lubin (Pre-Carpathians), and IvanoFrankove (Roztochia) are fish ponds so they belong to clean enough ones according to the results. The rest of the ponds: Cholgyni (the sedimentation reservoirs of industrial company "Sirka" filled up by water) (Roztochia), Perekalky (a derivation canal of Dobrotvir thermoelectric station) and Zhovtantsi (ponds of anthropogenic origin located in the village) (Lesser Polissia) belong to slightly contaminated category.

As far as such phenes as middorsal stripe and femur and tibia coloration depend on the conditions of amphibian habitat (Table 2) we carried out the analysis of variability of the phenes in the water bodies of different categories by water purity degree.

Clearly seen variant of middorsal stripe is the most common phene among the amphibians of all investigated Pelophylax species. We didn't find any individual of Pool Frog (Pelophylax lessonae) without it. Fig. 4 shows the variability of middorsal stripe depending on water quality. Obviously, the clearly seen middorsal stripe is the most numerous in clean and clean enough water bodies. The frequency of slightly seen and absent variants of middorsal stripe is increasing when the contamination level of water is increasing too. With the increasing of chemical contamination individuals of Pelophylax esculentus complex are more polymorphic by middorsal stripe with the increasing of rare variants portion of this feature. This tendency was confirmed for all three species. According to the results we can say also that the absence of middorsal stripe isn't peculiar to Pool Frog. The literature affirms that middorsal stripe can assist in individual

ISSN 1996-4536 (print) • ISSN 2311-0783 (on-line) • Біологічні Студії / Studia Biologica • 2017 • Том 11/№1 • С. 161-168 
firmness to drought and heavy metals permeability [3, 17, 19]; it also says that the same feature can increase skin permeability for sodium ions that results in decreasing of oxygen intake and decreasing of excitation threshold [19].

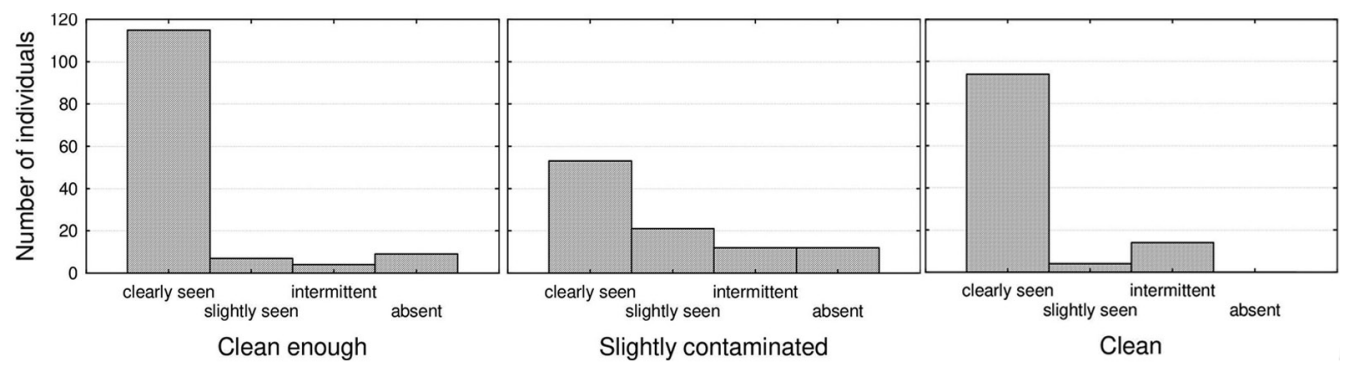

Fig. 4. The expression rate of middorsal stripe in water frogs from the water bodies of different water quality classes

Рис. 4. Стан прояву дорзомедіальної смуги у зелених жаб, відібраних із водойм різного класу якості води

The next phenotypic feature that was found out to be dependent on habitat conditions is femur and tibia coloration. This feature has to be analyzed on perpendicularly bended hind limbs only. Intermittent cross stripes on femur and tibia is the most characteristic variation of the feature among the amphibians of all investigated Pelophylax species (Pelophylax ridibundus - 50 \%, Pelophylax lessonae - $49 \%$ and Pelophylax esculentus - $55 \%$ ).

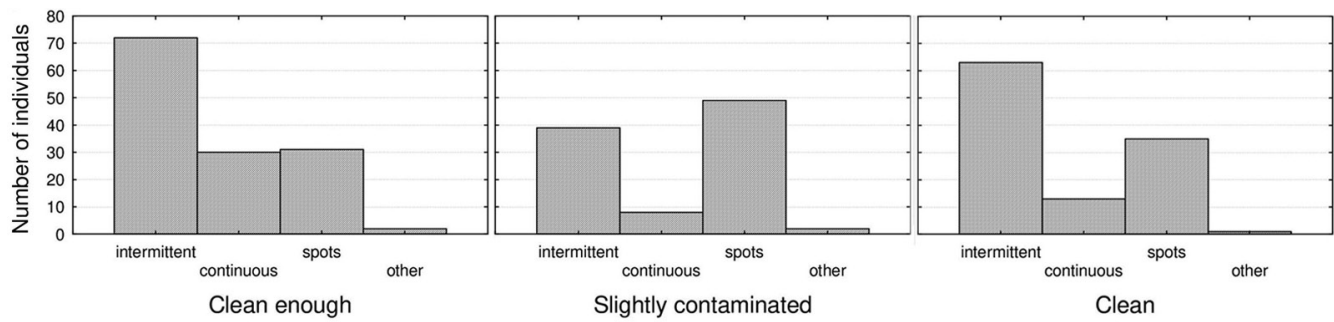

Fig. 5. The expression rate of femur and tibia coloration in water frogs from the water bodies of different water quality classes

Рис. 5. Стан прояву забарвлення стегна та гомілки у зелених жаб, відібраних із водойм різного класу якості води

Fig. 5 shows the obvious ratio change of the most common phene variants of femur and tibia coloration: the domination of intermittent cross stripes for clean and clean enough aquatic ecosystems and the domination of spotty hind limbs for slightly contaminated ones.

"Other"-group individuals occurred rarely and sporadically. In spite of our assumption about the affiliation of this phene variant with hybrid species Pelophylax esculentus, the analysis of species distribution by the expression rate of given feature has shown its presence only in the parental species.

\section{CONCLUSIONS}

1. The dependence of expression rates of all the analyzed phenotypes on physicochemical conditions of the habitat was found out. Dorsal coloration and presence of yellow spots on the thigh depend on the species of frog. Ventral coloration, throat color- 
ation and presence of snout stripes are the phenes which status is defined by the individual age stage. Eyes color and dorsal maculation depend on three factors: habitat conditions, the species of frog, and the individual age stage.

2. The expression rates of middorsal stripe depend mostly on habitat conditions of amphibians. Most often the individuals with clearly seen middorsal stripe occure. With the increasing of chemical contamination frogs become more polymorphic, i.e., the number of rare variants of the feature increases (slightly seen stripe and intermittent one). The presence of different variants of this phene is typical for Pelophylax lessonae (clearly seen, slightly seen and intermittent stripe).

3. Physicochemical conditions of habitat is a dominant factor in causing the expression rate of femur and tibia coloration. In the consequence of increasing of water contamination the frequency of individuals with spots on femur and tibia is increasing too, while in clean and clean enough waters more common are frogs with intermittent cross stripes. The combination of different variants of the feature as well as its absence in Pelophylax ridibundus and Pelophylax lessonae was noticed.

1. Alekin O.A. The basics of hydrochemistry. Leningrad: Gidrometeoizdat, 1970. 412 p. (In Russian).

2. Bannikov A.G., Darevsky I.S., Ishchenko V.G. et al. The key to amphibian and reptilian fauna of the USSR. A manual guide for students of biol. specialties of pedagogical institutes. Moscow, Prosveshcheniye. 1977. 415 p. (In Russian).

3. Belova Y.V. Interrelation of polymorphism phenomenon in populations of the Lake Frog with the habitat transformation. Yestestv. Nauki, 2009; 4(29): 9-15. (In Russian).

4. Bondartsev A.S. Color Scale: A Handbook for Biologists in Scientific and Applied Research. Moscow, Publishing house of the Academy of Sciences of the USSR. 1954. 27 p. (In Russian).

5. Hoffman, E.A., M.S. Blouin. A review of colour and pattern polymorphisms in anurans. Biological Journal of the Linnean Society, 2000; 70: 633-665.

6. Ishchenko V.G. Dynamic polymorphism of brown frogs of fauna of the USSR. Moscow, Nauka. 1978. 148 p. (In Russian).

7. Khalafyan A.A. Statistical analysis of data. $3^{\text {rd }}$ ed. Textbook. Moscow, Binom-Press. 2007. 512 p. (In Russian).

8. Nekrasova O.D. Interspecific Variability and Colouring Polymorphism of Green Frogs of Rana esculenta complex (Amphibia, Ranidae) in Hybrid Populations. Journal of Zoology, 2002; 36(4): 47-54. (In Russian).

9. Romanenko V.D., Zhukynskyy V.N., Oksyuk A.P. et al. Methods of establishing and using environmental standards of surface waters and estuaries of Ukraine. Kyiv, Dnipro. 2001. 48 p. (In Ukrainian).

10. Shabanov D.A., Zinenko O.I., Korshunov O.V. et al. The study of population systems of Green frogs (Rana ecsulenta complex) in Kharkiv region: history, modern condition and prospects. Visnyk of the Kharkiv University. Series Blology, 2006; 3 (729): 208-220. (In Russian).

11. Stakh V., Belokon M., Khamar I. et al. Morphological and genetic polymorphism of Green frogs (Pelophylax) in water bodies of Western Ukraine. Visnyk of the Lviv University. Series Blology, 2014; Issue 64: 241-249. (In Ukrainian).

12. Suryadnaya N.N. Green frogs of Ukrainian fauna: morfological variability, cariology, and peculiarities of biology: Abstract of dissertation for $\mathrm{PhD}$ degree [speciality] 03.00.08 zoology / I.I. Schmalhausen Institute of Zoology. 2005. 20 p. (In Ukrainian)

13. Sytnyk Y.M., Shevchenko P.G., Maystruk I.A. et al. Hydrochemical studies of lake ecosystems of Shatsk National Park: lake Luky-Peremut. State of biodiversity and ecosystems of Shatsk National Park. Conference materials (10-13 September 2009, Shatsk). Lviv, Spolom. 2009. 91-97 p. (In Ukrainian). 
14. Sytnyk Y.M., Shevchenko P.G., Maystruk I.A. et al. Hydrochemical studies of lake ecosystems of Shatsk National Park: Pisochne lake. State of biodiversity and ecosystems of Shatsk National Park. Conference materials (10-13 September 2009, Shatsk). Lviv: Spolom, 2009. 98-106 p. (In Ukrainian).

15. Sytnyk Y.M., Shevchenko P.G., Morozova A.O. et al. Hydrochemical studies of lake ecosystems of Shatsk National Park: 1948-2010 (a review). State of biodiversity and ecosystems of Shatsk National Park. Conference materials (8-11 September 2011, Shatsk). Lviv, Spolom. 2011. 94-99 p. (In Ukrainian).

16. Tarashchuk S.V. To the method for determining European green frogs of the group Rana esculenta (Amphibia, Ranidae). Vestn. Zool, 1985; 3: 83-85. (In Russian).

17. Vershinin V.L. Morpha striata in representatives of the genus Rana (Amphibia, Anura), the reasons of adaptability to environmental changes. Journal of General Biology, 2007; 68(6): 491-497. (In Russian).

18. Yablokov F.V. Population Biology: Textbook for Univer. biol. specialists. Vysshaya Shkola. Moscow, 1987. 303 p. (In Russian).

19. Zhelev Zh., Arnaudov At., Boyadzhiev P. Colour polymorphism, sex ratio and age structure in the populations of Pelophylax ridibundus and Pseudepidalea viridis (Amphibia: Anura) from anthropogenically polluted biotopes in Southern Bulgaria and their usage as bioindicators. Trakia Journal of Sciences, 2014;1: 1-12.

\title{
ФЕНИ ЗЕЛЕНИХ ЖАБ (РЕLОРНYLАХ) ЯК ІНДИКАТОРИ ЗАБРУДНЕННЯ ВОДОЙМ ПРИКАРПАТТЯ, РОЗТОЧЧЯ, МАЛОГО ТА ЗАХІДНОГО ПОЛІССЯ
}

\begin{abstract}
В. О. Стах ${ }^{1}$, І. С. Хамар ${ }^{1}$, О. С. Решетило ${ }^{1}$, Ю. М. Забитівський²
1 Львівський національний університет імені Івана Франка вул. Грушевського, 4, Львів 79005, Україна

2 Львівська дослідна станиія Інституту рибного господарства НААН вул. Львівська, 11, смт Великий Любінь, Городоцький р-н, Львівська обл. 81555, Україна e-mail: vasulunastax@gmail.com

Представлено результати аналізу фенотипної мінливості земноводних групи зелені жаби (Pelophylax) у залежності від внутрішніх і зовнішніх фракторів впливу. Для аналізу відібрано 345 особин трьох видів - жаби озерної, жаби ставкової та жаби їстівної з водойм різного антропогенного навантаження. Проаналізовано гідрохімічний склад води досліджуваних гідроекосистем і проведено класифікацію водойм за якістю води. Для дев'яти фенотипів встановлено залежність у прояві станів ознак від виду, віку та класу якості води. Усі аналізовані фени у своєму прояві мають значну залежність від умов середовища проживання земноводних. Встановлено, що прояв станів дорзомедіальної смуги, а також забарвлення стегна та гомілки залежать переважно від ступеня забруднення водойм. Зі збільшенням хімічного забруднення змінюється співвідношення альтернативних станів дорзомедіальної смуги та забарвлення стегна й гомілки. Зафріксовано не описані раніше прояви у забарвленні стегна та гомілки. Представники групи Pelophylax із найбільш забруднених водойм (Чолгині, Перекалки та Жовтанці) проявляли найбільшу мінливість аналізованих фенів.
\end{abstract}

Ключові слова: Pelophylax esculentus complex, поліморфізм, гідрохімія, дорзомедіальна смуга, забарвлення стегна та гомілки.

Одержано: 15.03.2017

ISSN 1996-4536 (print) • ISSN 2311-0783 (on-line) • Біологічні Студії / Studia Biologica • 2017 • Том 11/№1 • C. 161-168 